\title{
Effect of Calendula arvensis extract on anti-melanogenesis and antimicrobial activity
}

\author{
Hyun-Soo Kim $^{1}$ (i)
}

\section{금잔화 추출물의 미백활성 및 항균 효과}

김현수 ${ }^{1}$

Received: 20 February 2019 / Accepted: 22 March 2019 / Published Online: 30 June 2019

(C) The Korean Society for Applied Biological Chemistry 2019

\begin{abstract}
At concentrations with little or no cytotoxicity, $C$. arvensis extract indicates the ability of high DPPH radical scavenging, inhibited tyrosinase activity, and decreased melanin content. The treatment of $\mathrm{B} 16 \mathrm{~F} 10$ cells with $C$. arvensis extract suppressed the protein expression of tyrosinase a dose-dependent manner. These results suggest that $C$. arvensis extract inhibits melanin synthesis by inhibiting tyrosinase expression and tyrosinase activity. In addition, $C$. arvensis extract showed antimicrobial activities against bacteria and yeast. These results indicate that $C$. arvensis extract may serve as nutraceutical and cosmeceutical agents.
\end{abstract}

Keywords Antimicrobial activity $\cdot$ Calendula arvensis $\cdot$ Melanin - Tyrosinase

\section{서 론}

아토피 피부염(atopic dermatitis)은 심한 소양증, 피부 병변의 특 정적인 모양 및 분포를 갖는 만성 재발성 피부염이며, 유전적,

Hyun-Soo $\operatorname{Kim}(\square)$

E-mail: hyun1006@jwu.ac.kr

${ }^{1}$ Department of Food science and Technology, Jungwon University, Chungbuk 28024, Republic of Korea

This is an Open Access article distributed under the terms of the Creative Commons Attribution Non-Commercial License (http://creativecommons. org/licenses/by-nc/3.0/) which permits unrestricted non-commercial use, distribution, and reproduction in any medium, provided the original work is properly cited.
면역적인 원인과 관련되어 있다고 알려져 있다[1]. 환경오염, 식 습관 및 스트레스 등으로 인해 아토피 피부염 환자는 급속히 증가할 것으로 전망되고 있다. 또한, 현대사회에 동양권 여성들 을 중심으로 아토피피부를 개선하고 미백효과가 있는 무독성인 천연물 소재에 대한 관심이 증가하고 있다[2]. 피부색은 자외선 과 같은 외부자극으로부터 피부를 보호하기 위해 합성되는 멜 라닌(melanin)의 양과 종류에 따라 결정되며 과도한 멜라닌 합 성과 축적은 색소 침착 증상을 동반하게 된다[3]. 멜라닌 형성 에는 tyrosinase 효소가 그 핵심 역할을 하고 있다[4]. 따라서 멜라닌 생성을 억제함으로써 미백효과뿐만 아니라 아토피 피부 염 악화를 제어하는 항균 효과가 있는 독성이 없는 소재개발이 요구되고 있다[4].

본 연구의 재료인 금잔화는 국화과의 한해살이풀로 남유럽이 원산지이다. 금잔화는 주성분인 사포닌(saponins)에 의한 부종에 의해 원인이 되는 염증성 질환에 효과[5]가 있으며 항균효과[6] 가 있다고 알려져 있다. 이와 같이 다방면의 생리, 화학적 기능 이 보고되어 있음에도 불구하고 미백활성 등 기능성소재에 활 용하기 위한 연구는 미미하다. 따라서 본 연구에서는 금잔화 지 상부 추출시료를 가지고 생리활성 및 미백시험, 멜라닌 생성 억 제시험 및 항균시험을 조사하여 기능성 소재로서의 활용 가능 성을 검토하고자 하였다.

\section{재료 및 방법}

\section{실험재료}

금잔화(Calendula arvensis) 지상부에 대한 추출물은 국립원예특 작과학원 인삼특작부 추출물은행에서 분양받은 시료를 실험에 이용하였으며 제시된 추출방법은 $\mathrm{Kim}$ 의 연구시료를 $\mathrm{Ahn}$ 의 연 구에서 명기된 방법[7]에 의해 수행되었다. 


\section{세포독성평가}

세포독성 시험은 $\mathrm{Kim}$ 의 연구에서 명기된 방법[8]에 의해 수행 하였다. 즉, 세포내의 미토콘드리아 수소제거효소에 의해 수용 테트라졸륨염(water soluble tetrazolium salts) (WST-1)에서 불 용성의 포마진(formazan)결정으로 변환되는 원리를 이용하였다 [9].

\section{산화방지력 측정}

$\mathrm{DPPH}$ 라디칼(Radical) 소거능 실험은 $\mathrm{Kim}$ 의 연구에서 명기된 방법[8]에 의해 수행하였다. 산화방지력은 [1-(시료첨가구의 흡 광도/무첨가구의 흡광도) $] \times 100$ 의 계산식에 의해 활성 $(\%)$ 을 구하 였다.

\section{Tyrosinase 억제활성측정}

타이로시네이즈 저해활성 측정은 $\mathrm{Kim}$ 의 연구에서 명기된 방법 [8]에 의해 수행하였다.

\section{멜라닌 생성 저해 측정}

멜라닌 정량은 $\mathrm{Kim}$ 의 연구에서 명기된 방법[8]에 의해 수행하 였다. 추출물을 처리하지 않은 시료군을 대조군으로 하고 결과 는 $\%$ 로 환산하였다.

\section{Western blot 분석}

금잔화 추출물에 의한 tyrosinase 단백질 발현을 분석하기 위하 여 western blot을 시행하였으며 방법은 $\mathrm{Kim}$ 의 연구에서 명기 된 방법[8]에 의해 수행하였다. 1차 항체(mouse anti-tyrosinase: 1:200, Abcam, Cambridge, UK; mouse anti- $\beta$-actin: 1:1000, Sigma-Aldrich Co., St. Louis, MO, USA)와 2차 항체(rabbit anti-mouse IgG-HRP: 1:5000, Santa Cruz Biotechnology, Carlsbad, CA, USA)를 반응시켰다. 단백질밴드는 광 이미지 시 스템(Chemi-Doc image system) (BIO-RAD, Hercules, CA, USA)기기를 사용하여 정량하였다.

\section{항균활성 측정}

시간별로 항균작용이 어떤 변화를 보이는지 알아보기 위해 timecurve를 작성하였다. 방법은 $\mathrm{Ahn}$ 등에 명기된 방법[7]에 의해 수행하였다. 각각 균주 배양액에 금잔화 추출물 최종농도가 100 $\mathrm{mg} / \mathrm{L}$ 이 되도록 처리한 후, 일정 시간별로 배양액을 채취하여 평판배지에 접종 후, 생성되는 군락(colony)의 수를 측정하고 $\mathrm{cfu} / \mathrm{mL}$ 로 환산하였다.

\section{통계처리}

모든 실험은 독립적으로 3 회 반복 시행하고 실험결과는 평균 \pm 표준편차로 표기하였으며, 통계처리는 $\mathrm{Kim}$ 의 연구에서 명기된 방법[8]에 의해 수행하였다. 즉, GraphPad Prism 5 program (GraphPad Software, Inc., La Jolla, CA, USA)을 이용하여 $p$ 값이 0.05 미만일 때 통계적으로 유의 하다고 판단하였다. 일원 배치 분산분석(one-way analysis of varience)을 한 후, 각 시료 간의 통계적 유의성은 Bonferroni's multiple comparison test를 이용하여 수행하였다.

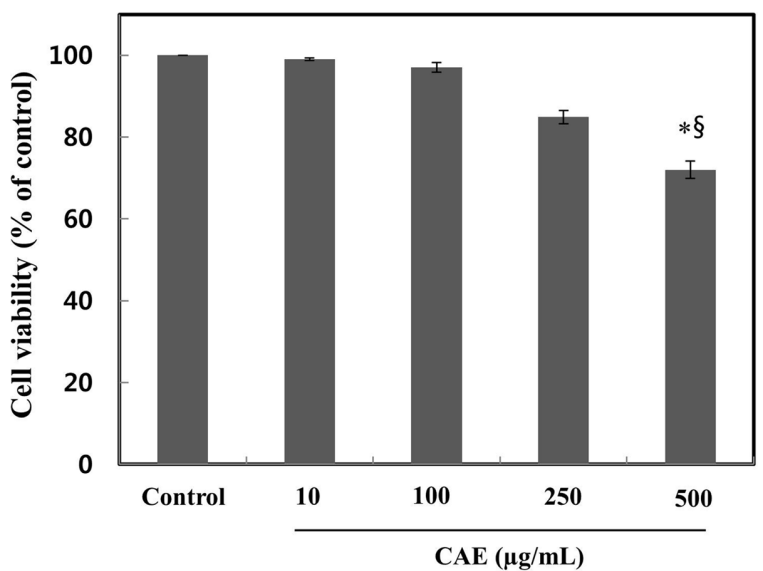

Fig. 1 Cell cytotoxicity of Calendula arvensis extract (CAE) on murine melanoma B16F10 cell. CAE-untreated group was used as a control. Values are presented as mean \pm SEM. Differences were considered statistically significant, ${ }^{*} p<0.05$ compared to the control group, ${ }^{\S} p<0.05$ compared to the CAE $10 \mu \mathrm{g} / \mathrm{mL}$ group

\section{결과 및 고찰}

\section{금잔화 추출물의 세포독성시험}

대조군 대비하여 금잔화 추출물(Calendula arvensis extract: CAE) $10,100,250,500 \mu \mathrm{g} / \mathrm{mL}$ 의 $\mathrm{CAE}$ 농도에서 각각 0 , $0.1,0.3,15.1,28.0 \%$ 로 나타났다(Fig. 1). 멜라닌 생성 억제 물 질로서 백합뿌리 추출물[10]인 경우, $100 \mu \mathrm{g} / \mathrm{mL}$ 이하에서 세포 독성이 거의 없다고 보고된 바와 같이, 금잔화 추출물도 안전 한 천연물질로 판단된다.

\section{금잔화 추출물의 산화방지 활성}

추출물 시료와 아스코빅산 대조구 시료를 각각 $10,50,100 \mu \mathrm{g}$ $\mathrm{mL}$ 의 농도로 제조하여 $\mathrm{DPPH}$ 소거활성을 측정한 결과(Fig. 2), $\mathrm{CAE}$ 각각에 대한 $10,50,100 \mu \mathrm{g} / \mathrm{mL}$ 의 추출물 농도에서는 대 조구와 거의 비슷한 라디칼 소거활성을 보였다 $(88.9,91.2$, $91.3 \%$ ). 또한, 미백효과 시료로서 보고된 대나무[11] 추출물의 경우, $50 \%$ 의 소거활성을 보이는 농도가 $100 \mu \mathrm{g} / \mathrm{mL}$ 이었던 것과 비교하면, 금잔화 추출물의 천연물 소재로서의 가능성을 확인할 수 있다.

\section{금잔화 추출물의 tyrosinase 저해활성}

금잔화 추출물에 대한 tyrosinase 저해활성을 관찰하였다(Fig. 3). $\mathrm{CAE} 10,50,100 \mu \mathrm{g} / \mathrm{mL}$ 의 경우, 각각 $7.2,25 ., 38.8 \%$ 의 tyrosinase 저해활성을 나타내었다. 표준시료인 kojic acid의 100 $\mu \mathrm{g} / \mathrm{mL}$ 경우에는 $44.7 \%$ 의 저해활성을 나타내었다. Kojic acid와 비교했을 때, 금잔화 추출물 저해활성 농도가 약간 낮았으며, 우수한 미백활성 효과로서 연구된 바[12] 있는 녹나무과 추출 물 $100 \mu \mathrm{g} / \mathrm{L}$ 의 경우에 $52.8 \%$ tyrosinase 저해활성을 보고한 것 을 고려하면, 미백 기능성 소재로서의 가능성이 높다고 생각된다. 


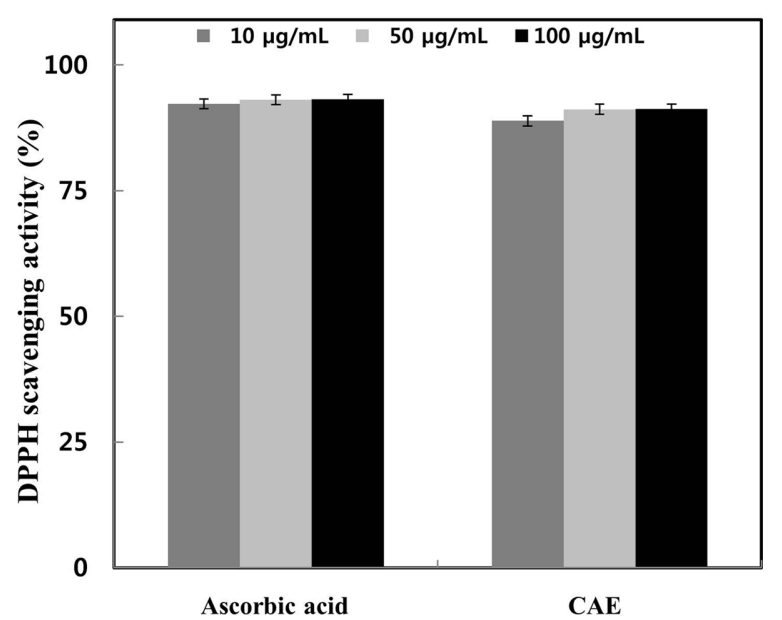

Fig. 2 Anti-oxidant effects of Calendula arvensis extract (CAE). Ascorbic acid was used as a positive control. Values are presented as mean \pm SEM. Differences were considered statistically significant

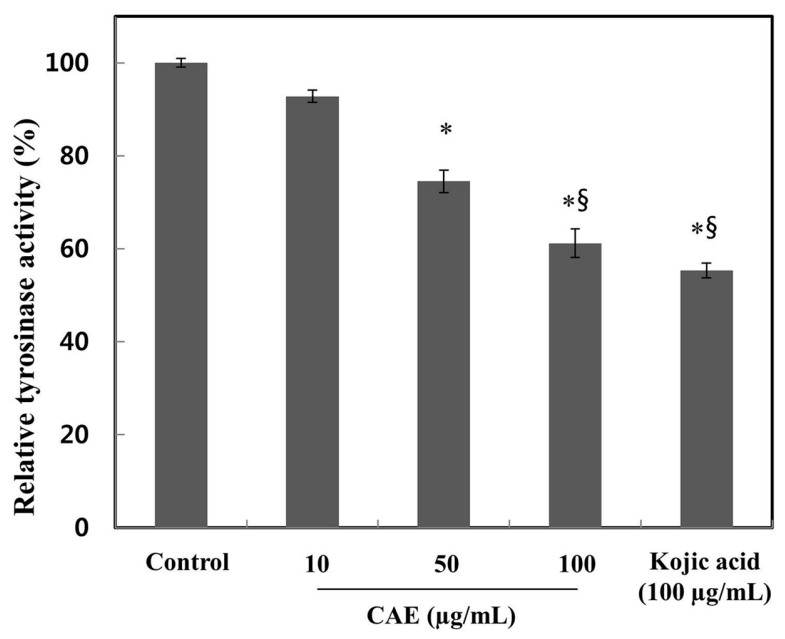

Fig. 3 Inhibitory effect of Calendula arvensis extract (CAE) on tyrosinase. The tyrosinase activity assay was performed with mushroom tyrosinase. Kojic acid was used as a positive control. CAE-untreated group was used as a control. Values are presented as mean $\pm \mathrm{SEM}$. Differences were considered statistically significant, ${ }^{*} p<0.05$ compared to the control group. ${ }^{\S} p<0.05$ compared to the CAE $10 \mu \mathrm{g} / \mathrm{mL}$ group

\section{금잔화 추출물의 멜라닌 생성 저해활성}

금잔화 추출물에 대한 세포독성 실험 측정에서 정한 독성이 없 는 농도에서 멜라닌 생성 저해 활성을 측정하였다(Fig. 4). 대 조군 대비하여 $10,50,100 \mu \mathrm{g} / \mathrm{mL}$ 의 $\mathrm{CAE}$ 농도에서 각각 31.5 , $44.3,67.9 \%$ 의 멜라닌 생성 억제 활성을 보였다. 다른 천연소재 중 미백활성 효과로서 보고된 바[13] 있는 솔잎 발효액 100 $\mu \mathrm{g} / \mathrm{mL}$ 의 경우 $53.3 \%$ 멜라닌 생성 저해활성을 보이는 것을 고 려하면 멜라닌 생성 저해 활성이 매우 우수함을 의미한다. 즉, 본 연구의 금잔화 추출물의 경우도 멜라닌 저해 활성이 우수하 였으며 이에 따른 tyrosinase 저해활성도 높았다.

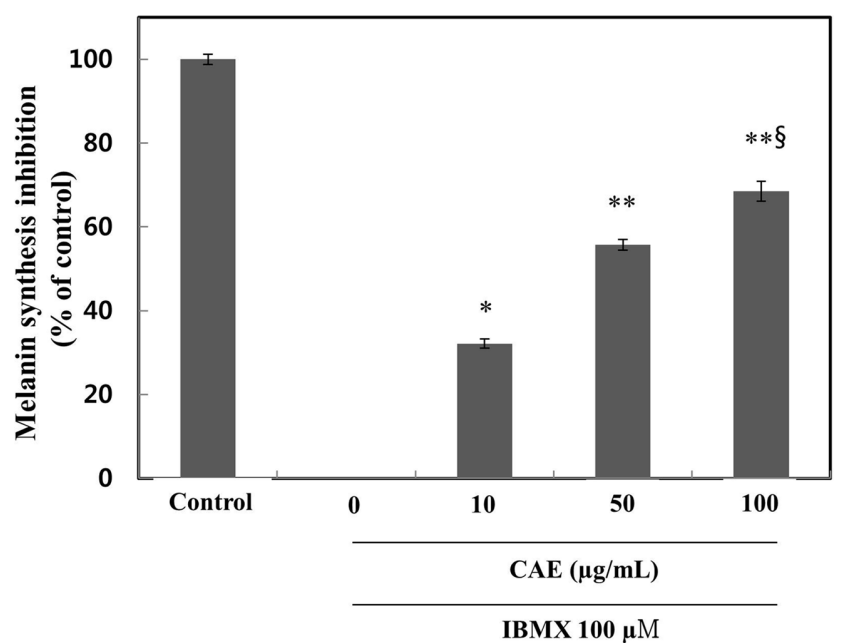

Fig. 4 Anti-melanogenic effects of Calendula arvensis extract (CAE). Cells were treated with $100 \mu \mathrm{M}$ IBMX in presence or absence of CAE at the indicated concentration for 2 days. Untreated group (both CAE and IBMX) was used as a control. Values are presented as mean $\pm \mathrm{SEM}$. Differences were considered statistically significant, ${ }^{*} p<0.05$, ${ }^{* *} p<0.01$ compared to the CAE-untreated group, ${ }^{\S} p<0.05$ compared to the CAE $10 \mu \mathrm{g} / \mathrm{mL}$ group

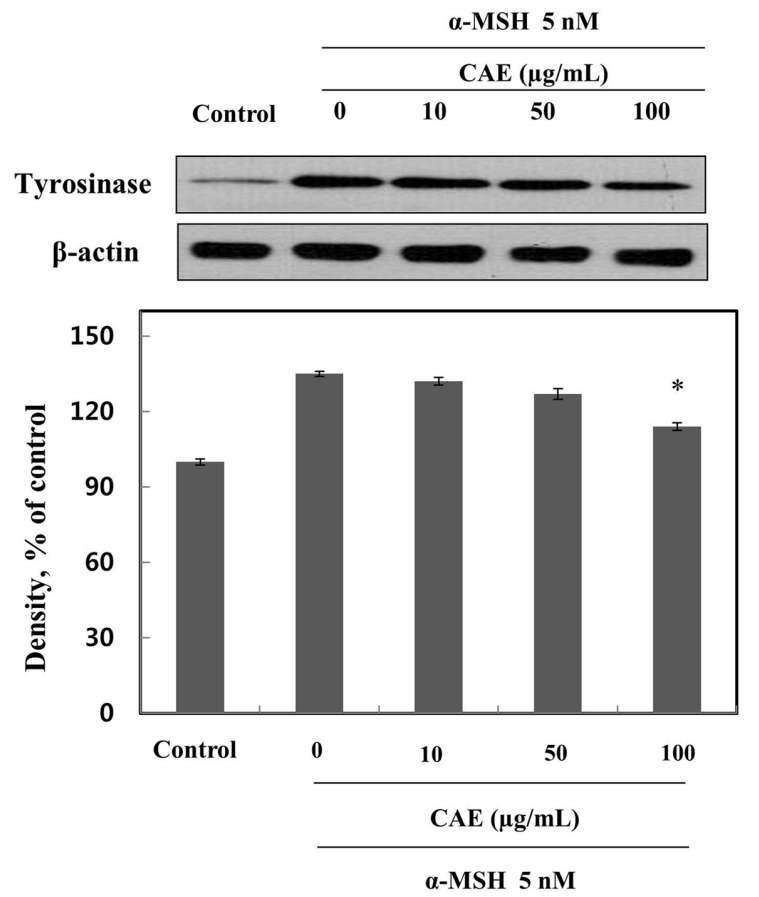

Fig. 5 Effect of Calendula arvensis extract (CAE) on expression of tyrosinase. Western blot analysis on expression of tyrosinase. Cells were treated with $5 \mathrm{nM} \alpha-\mathrm{MSH}$ in presence or absence of CAE at the indicated concentration for 2 days. $\beta$-actin was used as an internal standard. Untreated group(both CAE and $\alpha-\mathrm{MSH}$ ) was used as a control. Values were nomalized to $\beta$-actin before calculating changes and presented as mean $\pm \mathrm{SEM}$. Differences were considered statistically significant, ${ }^{*} p<0.05$ compared to the CAE-untreated group 
Bacillus subtilis

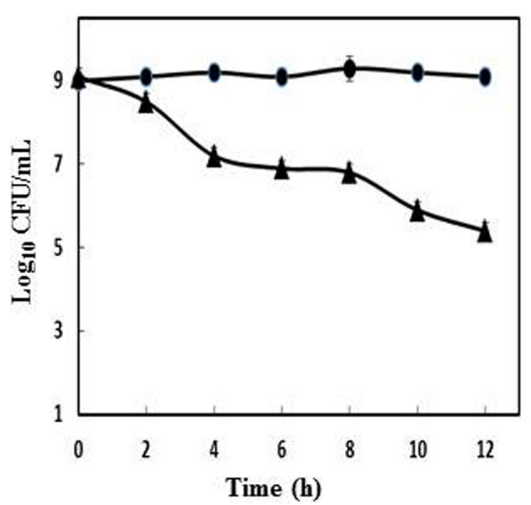

Escherichia coli

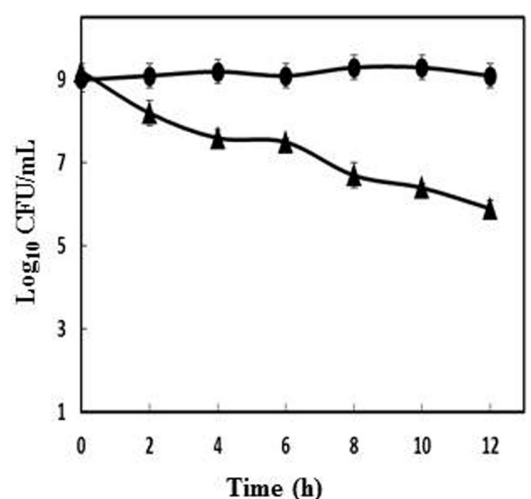

Candida albicans

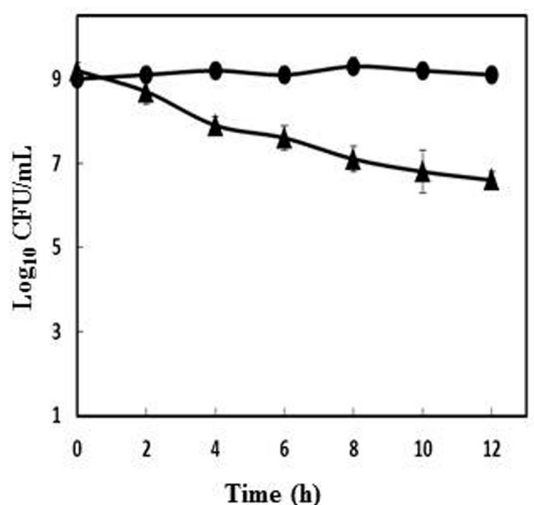

Fig. 6 Anti-microbial effect of Calendula arvensis extract (CAE). Time-curve of CAE against B. subtilis, E. coli and C. albicans. 10\% DMSO was used as a negative control

and CAE was dissolved in $10 \%$ DMSO to a final concentration of $100 \mathrm{mg} / \mathrm{L}$

\section{금잔화 추출물의 tyrosinase 발현 억제 효과}

Tyrosinase 단백질 발현에 미치는 금잔화 추출물에 의한 영향을 조사하였다(Fig. 5). 대조군 대비하여 $\alpha-\mathrm{MSH}$ 와 함께 각각 무 처리, $10,50,100 \mu \mathrm{g} / \mathrm{mL}$ 의 $\mathrm{CAE}$ 농도에서 각각 141,132 , $127,114 \%$ 로 농도 의존적으로 tyrosinase 발현이 억제되었다. 따 라서 금잔화 추출물의 경우, tyrosinase 활성저해는 tyrosinase 단백질 발현억제 효과[14] 혹은 멜라노좀 수송 저해[15] 등 다 른 요인에 의해 멜라닌 생성이 억제된 것으로 판단된다. 한편, 금잔화 꽃 추출물 연구[16]에서 산화방지 활성 및 tyrosinase 활 성저해 등을 보고한 것에 비해 본 연구의 지상부 추출물에서 좋은 활성을 보인 것으로 볼 때 꽃 이외의 지상부에 활성성분 이 많이 포함되어 있을 것으로 예상된다.

\section{금잔화 추출물의 항균 효과}

대조군의 경우 시간이 경과함에 따라 균의 성장에 변함이 없었 으나 금잔화 추출물 시료처리 경우는 배양 12 시간 경과 후, Bacillus subtilis, Escherichia coli, Candida albicans 각각 대 조군에 대하여 $40.7,35.2,27.5 \%$ 의 증식 억제가 확인되었다 (Fig. 6). 또한, 그람양성균인 B. subtilis에 대한 증식억제 효과 가 가장 높게 나타났다. 다른 연구에서 Candida 속 균주들에 대 한 항균효과를 보고한[6]바와 같이 금잔화 추출물(CAE)은 항균 력이 우수하였으며, 아토피 피부염 개선 및 천연방부제로서의 활용 가능성이 있을 것으로 생각한다.

\section{초 록}

본 연구에서 금잔화(Calendula arvensis)에 대한 다양한 생리, 화학적 활성을 시험하여 기능성소재 가능성을 검토하였다. 금잔 화 추출물은 낮은 세포독성을 나타냈다. 세포독성이 거의 없는 농도에서 금잔화 추출물 처리 시, 산화방지 활성, tyrosinase 활 성저해 및 멜라닌 함량 저하를 보여주었다. 금잔화 추출물 농 도에 따라 tyrosinase 단백질 발현이 억제되었으며, 이는 금잔화 추출물이 tyrosinase의 활성 및 단백질 발현을 억제시키거나 혹 은 멜라노좀 수송 저해 등 다른 요인에 의해 멜라닌 합성을 저
해하는 것으로 생각된다. 또한, 금잔화 추출물 처리 시, 항균활 성이 나타남을 확인하였다. 따라서 금잔화 추출물은 향후 기능 성 소재에 활용할 수 있는 효과적인 물질이 될 수 있다고 판단 된다.

Keywords 금잔화 추출물 - 멜라닌 · 타이로시네이즈 · 항균활성

Acknowledgments 본 연구는 2017년도 교육부와 한국연구재단(NRF)의 이 공분야기초연구지원사업의 지원(2017R1D1A1B03031402)에 의해 수행되었 으며, 국립원예특작과학원 인삼특작부 추출물은행(과제번호 PJ009629)으로 부터 제공받은 추출물을 재료로 사용하였음으로 이에 감사 드립니다.

\section{References}

1. Lawton S (2014) Atopic eczema: the current state of clinical research. $\mathrm{Br}$ J Nurs 23: 1061-1066

2. Sohn ES, Kim SW, Kang JS, Lee SP (2004) Technology trend patent information analysis of cosmetic materials derived from natural products. Appl Chem 8: 466-469

3. Hill HZ, Li W, Xin P, Michell DL (1997) Melanin: a two edged sword? Pigment cell Res 10: 158-161

4. Kobayashi T, Urabe K, Winder AJ, Jimenez-Cervantes C. Imokawa G, Brewington T, Solano F, Garcia-Borron JC, Hearing VJ (1994) Tyrosinase related protein-1 (TRP-1) function as a DHICA oxidase in melanin biosynthesis. EMBO J 3: 5818-5825

5. Chemli R, Toumi A, Oueslati S, Zouaghi H, Boukef K, Balansard G (1990) Calendula arvensis L. Impact of saponins on toxicity, hemolytic effect, and anti-inflammatory activity. J Pharm Belg 45: 12-16

6. Abudunia AM, Marmouzi I, Faouzi ME, Ramli Y, Taoufik J, El Madani N, Essassi EM, Salama A, Khedid K, Ansar M, Ibrahimi A (2017) Anticandidal, antibacterial, cytotoxic and antioxidant activities of Calendula arvensis flowers. J Mycol Med 27: 90-97

7. Ahn JJ, Hwang TW, Kim HS (2015) Study on the physiological activities of Cleyera japonica extract Kor J Plant Res 28(2): 153-157

8. Kim HS (2018) Effect of Abelmoschus esculentus extract on antimelanogenesis and skin barrier function. Kor J Food Sci Technol 50: 344-348

9. Ranke J, Mölter K, Stock F, Bottin-Weber U, Poczobutt J, Hoffmann J, Ondruschka B, Filser J, Jastorff B (2004) Biological effects of imidazolium ionic liquids with varying chain lengths in acute Vibrio 
fischeri and WST-1 cell viability assays. Ecotoxicol Environ Saf 58: 396-404

10. Yoon HS, Yang KW, Kim JE, Kim JM, Lee NH, Hyun CG (2014) Hypopigmenting effects of extracts from bulbs of Lilium oriental hybrid 'Siberia' in murine B16/F10 melanoma cells. J Kor Soc Food Sci Nutr 43: 705-711

11. Song HS, Moon HJ, Park BE, Choi BS, Lee DJ, Lee JY, Kim CJ, Sim SS (2007) Anti-oxidant activity and whitening activity of bamboo extracts. J Pharm Soc 51: 500-507

12. Jin KS, Lee JY, Kwon HJ, Kim BW (2013) Anti-Oxidative, antiInflammatory, and anti-melanogenic activities of Endlicheria anomala extract. Kor J Microbiol Biotechnol 41: 433-441

13. Han JS, Yi DH (2012) Effects of pine needles fermentation extracts on antioxidant activity and inhibition of melanin synthesis. Kor J Aesthet Cosmetol 10: 619-624

14. Kim B, Lee SH, Choi KY, Kim HS (2015) N-nicotinoyl tyramine, a novel niacinamide derivative, inhibits melanogenesis by suppressing MITF gene expression. Eur J Pharmacol 764: 1-8

15. Kim B, Hwang JS, Kim HS (2015) N-nicotinoyl dopamine inhibits skin pigmentation by suppressing of melanosome transfer. Eur J Pharmacol 769: $250-256$

16. Lee KK, Kwon HS, Song YS, Kim MK (2015) A Study on the composition and antioxidant activity of Calendula arvensis Flower extracts as beauty cosmesutical ingredients. J Kor Soc Cosmetol 21: 1101-1107 